УДК $821.111(73)-31-055.2$

DOI: $10.15421 / 3820018$

S. Honsalies-Munis

С. Ю. Гонсалєс-Муніс

С. Ю. Гонсалес-Мунис

Oles Honchar Dnipro National University

Дніпровський начіональний університет імені Олеся Гончара

Днепровский национальный университет имени Олеся Гончара

\title{
MULTICULTURAL PECULIARITIES OF LINGUACULTURAL REALIA IN THE NOVEL 'JAZZ' BY TONY MORRISON
}

\section{МУЛЬТИКУЛЬТУРНІ ОСОБЛИВОСТІ ЛІНГВОКУЛЬТУРНИХ РЕАЛІЙ В РОМАНІ ТОНІ МОРРІСОН «ДЖАЗ»}

\section{МУЛЬТИКУЛЬТУРНЫЕ ОСОБЕННОСТИ ЛИНГВОКУЛЬТУРНЫХ РЕАЛИЙ В РОМАНЕ ТОНИ МОРРИСОН «ДЖАЗ»}

The article deals with the issue of linguistic and cultural realia and their peculiarities in Tony Morrison's novel «Jazz». The study is carried out in the multicultural aspect and begins with the detailed analysis of the terms 'multiculturalism' and 'multicultural literature'. The theoretical background of the article is based on the works of Taylor, Sanders, Gutmann, Zverev, Tolkachev, Denisova, Tlostanova in which they defined the concept of multiculturalism and dwelled on the issues of ethnic literatures and their peculiarities.

The article focuses on the specific features of the multicultural phenomenon in AfricanAmerican society, on the issues of the national identity and language identity of African-American people. The article outlines the major means of expression the national and cultural code in the artistic text, gives the definition of the term 'realia', emphasizes the importance of these linguistic means in conveying the authentic cultural atmosphere of the text. Characteristic features of the novel «Jazz» are analyzed in the research as well as the use of various linguo-cultural devices such as anthroponyms, toponyms, cultural and historical realia, symbols, allusions, cultural myths. The peculiarities of the language of the protagonists are also studied in detail, such as the use of African American Vernacular English. The article outlines the brightest examples of the combination of language and culture in the work of fiction in the multicultural aspect.

Keywords: multiculturalism, national identity, language identity, national and cultural code, African-American identity, cultural realia, onomastics, anthroponym, toponym, jazz polyphony.

Досліджено особливості використання лінгвокультурних реалій в романі Тоні Моррісон «Джаз». Дослідження проводиться у мультикультурному аспекті і починається 3 докладного аналізу понять «мультикультуралізм» і «мультикультурна література». Теоретична база статті заснована на роботах Тейлора, Сандерс, Гутмана, Звєрєва, Толкачева, Денисової, Тлостанової, в яких вони визначили концепцію мультикультуралізму і описали проблеми національних літератур та їх характерні риси.

Розглянуто особливості мультикультурності в афро-американському суспільстві, проблеми національної самосвідомості і мовної ідентичності афро-американського народу. У даній роботі проаналізовано основні засоби вираження національного та культурного коду в художньому тексті, дано визначення терміна «реалія», наголошено на важливості цих мовних засобів для відтворення аутентичної культурної атмосфери тексту. Характерні особливості роману «Джаз», використання різних лінгвокультурних реалій, а саме: антропонімів, топонімів, історичних та культурних реалій, символів, алюзій, культурних міфів детально розглянуто у статті. Особливості мови героїв роману також беруться до уваги, зокрема, використання афро-американського діалекту в англійській мові. Наведено найяскравіші приклади посднання мови та культури в художньому творі в мультикультурному аспекті.

\footnotetext{
(C) Honsalies-Munis S., 2020
} 
Ключові слова: мультикультуралізм, національна ідентичність, мовна ідентичність, національний і культурний код, афро-американська ідентичність, культурні реалії, ономастика, антропонім, топонім, джазова поліфонія.

Рассмотрены лингвистические и культурные реалии в романе Тони Моррисон «Джаз». Исследование проводится в мультикультурном аспекте и начинается с подробного анализа понятий «мультикультурализм» и «мультикультурная литература». Теоретическая база статьи основана на работах Тейлора, Сандерс, Гутмана, Зверева, Толкачева, Денисовой, Тлостановой, в которых они определили концепцию мультикультурализма и описали проблемы национальных литератур и их особенности.

Рассмотрены особенности мультикультурности в афро-американском обществе, проблемы национального самосознания и языковой идентичности афро-американского народа. В данной работе проанализированы основные средства выражения национального и культурного кода в художественном тексте, дано определение термина 'реалия', подчеркнута важность этих языковых средств в передаче подлинной культурной атмосферы текста. Характерные особенности романа «Джаз», использование различных лингвокультурных реалий - антропонимов, топонимов, исторических и культурных реалий, символов, аллюзий, культурных мифов - детально рассмотрены в статье. Особенности языка героев романа также берутся во внимание, в частности, использование афро-американского диалекта в английском языке. Приведены самые яркие примеры сочетания языка и культуры в художественном произведении в мультикультурном аспекте.

Ключевые слова: мультикультурализм, национальная идентичность, языковая идентичность, национальный и культурный код, афро-американская идентичность, культурные реалии, ономастика, антропоним, топоним, джазовая полифония.

The article deals with means of expressing multicultural peculiarities of linguacultural realia in the novel «Jazz» by Toni Morrison. In the introduction to the American E-journal Multicultural Literature in the United States Today it is mentioned that for 500 years, immigrants from diverse cultures have sought freedom and opportunity in what is now the United States of America. The writers among them recorded their experiences in letters, journals, poems, and books, from early colonial days to the present. "We are a nation of many voices,» writes Marie Arana in her essay bearing the same title. Multicultural studies try to show how voices from various ethnic backgrounds have enriched American society through art and cultural sharing that invites understanding [7].

One of the leading areas of modern American studies is the study of the multicultural phenomenon, the problems of intercultural communication and borderland on the artistic material of ethnic literatures, which include Native American, African American, MexicanAmerican, and Asian-American. As multifaceted cultural phenomena have already taken place, these literatures constantly attract the attention of scientists representing various branches of knowledge. Among domestic literary scholars who made a significant contribution to the study of ethnic literatures and related problems, should be noted Y. N. Zasursky, A. S. Mulyarchik, A. M. Zverev, T. N. Denisova, A. V. Vashchenko, M. V. Tlostanova. In their writings, there is a general tendency to consider the work of ethnic authors of the United States in the context of its interaction with the «mainstream».

The model of a multicultural society was formed by the Canadian researcher Charles Taylor, which is based on the fact that restraint and tolerance towards immigrants is not enough, they should receive equal rights while maintaining their internal cultural status and habitual life [15, p.38]. The concept is characterized by the concept of recognition of representatives of other cultures as full members of society, that is, otherness should not exist as a difference, but as a recognized phenomenon within the framework of a single culture. 
American scholar Linda A. Sanders defines multicultural literature as part of literature that includes all literary genres, but mainly focuses on main characters who are members of unrepresented groups whose racial, ethnic, religious, sexual orientation or culture has historically been marginalized or misrepresented by the dominant culture [13, p. 194].

Contemporary Japanese scholar J. Yokota suggests that multicultural literature includes literature about people who are considered outside the mainstream of society, with diverse cultural, linguistic, socioeconomic, and religious backgrounds. In addition, it encompasses issues on gender, sexual orientation, and disabilities [18, p. 156-157]. Sarah Song, in The Stanford Encyclopedia of Philosophy, defines the term «multicultural» as a descriptive term to characterize the fact of diversity in a society, but in what follows, the focus is on its prescriptive use in the context of Western liberal democratic societies [14, p.1]. Thus, Afro-American literature has become a means of enhancing the self-identity of their race, an attempt to find their place in American history on the whole.

Having thoroughly analyzed the manifestations of multiculturalism in a literary text, Sergey Tolkachev comes to the conclusion that the fluctuations, metaphysical, emotional, between the center and the periphery, the culture of the native and the new, are a common metaphor in the work of emigrant writers, which is facilitated by the fact of literary creation in a non-native language in another medium [6, p. 178].

In the works of multicultural writers, myth and history often receive a new interpretation, and provide the works with an original neo-mythological context. The text «inserts» the culture into the text itself as a demonstration of a specific cultural «extract». Technically, this is expressed in the use by the writer of untranslated words, language and cultural realia, special sounds, for which certain language structures are used. Such inclusions of authentic culture in themselves become a metaphor for the cultural and national identity in question [6, p. 180].

Multiculturalism is closely associated with «identity politics,» «the politics of difference,» and «the politics of recognition,» all of which share a commitment to revaluing disrespected identities and changing dominant patterns of representation and communication that marginalize certain groups (Gutmann 2003, Taylor 1992, Young 1990). S. Song states that multiculturalists take for granted that it is «culture» and «cultural groups» that are to be recognized and accommodated [14, p.1]. Language and religion are at the heart of many claims for cultural accommodation by immigrants. The key claim made by minority nations is for self-government rights. According to M. K. Popova, literature is a relevant source of information on the problem of national identity, where the national mentality of the characters is expressed through the system of artistic means used by the author. Being considered and analyzed as one unity, such a system certainly provides objective information about reality. However, to identify this objectivity, it is necessary to master modern methods of literary and cultural analysis, which allow the researcher to read and decode the cultural codes hidden in the work [4, p. 46]. And linguacultural realia can become one of the means to deal with these cultural codes. Among other artistic means expressing the national mentality and the national conceptual sphere, a prominent place belongs to the national image, symbols and artistic details.

The 20th century in America witnessed rapid social changes, the development of the women's movement, the emergence of the problems of the role and fate of women in society, and the problems of a multicultural society. African American writer Tony Morrison, the first African American Nobel Prize winner in literature, reflected in her works the influence of racism, enslavement and oppression based on cultural, racial, social differences. An analysis of Tony Morrison's work is relevant not only because 
it has not been studied enough in the national literature and language studies, but also because the writer masterly reveals her creative potential in portraying national identity in the context of a multicultural paradigm of an American society.

In her novels Tony Morrison explores a society in which racism is widespread and has a dramatic effect on lives of characters. Every novel is a combination of real stories and parables with very deep psychological and philosophical overtones. In her literary heritage T. Morrison reflects the main trends in African-American literature in the second half of the twentieth century. She understands the slavery not only as a stage in American history, but also as part of the black American consciousness and culture. African Americans differentiate themselves by their social status and group affiliation, being aware of their place in the world. And they realize their ethnic identity, their belonging to the African American community as a result of common historical memory, memories about common ancestors and emotional ties with the homeland. They understand that there are social boundaries between races and they must demonstrate the white people the knowledge of their «place» and their desire to stay in this «place» [10, p.42].

The writer uses folklore motifs in the plots of her novels as an expressive means in describing characters, most protagonists of her novels are assembled from many elements (mythological idea of the ancestor, their treatment of folklore and the author's reinterpretation), they become a means of expressing the duality, or rather multiplicity of the worldview of African American men and, what is more often, women.

In the study of the national and cultural content of a language and an artistic text many scientists often pay a lot of attention to realia. We suppose that language and cultural realia can become productive tools in analyzing the national conceptual sphere of the text. They help to feel the multicultural character of the text as well as focus on some specific cultural representations. But what do we have in mind when we use the term realia?

In the culture of every nation, there are concepts, phenomena, objects, that are characteristic only for this certain nation and connected with its historical and geographical, socio-political, and other conditions of existence. Contemporary scholar N. Musina suggests that the issue of relations between culture in the broadest sense of the word and the information that is contained, stored and conveyed in the words represented as language elements, since olden times has attracted not only linguists, but also representatives of other sciences. All features of the life of the people such as natural conditions, geographical location, historical development, social structure, the tendency of social thought, science, and art are necessarily reflected in the language of the people. Therefore, we can say that the language is a reflection of the culture of any nation, it bears a national-cultural code of a particular nationality. In every language there are words meanings of which reflect the relationship of language and culture, which is called the cultural component of the semantics of language units. These words are primarily realia words [3, p. 481-484].

There are several definitions of realia. According to the definition of O. S. Akhmanova, realia are «variety of factors, being studied by foreign linguistics, such as state structure, history and culture of the specific nation, linguistic communication between native speakers in terms of their reflections in the language» [1, p. 475]. A. D. Schweitzer defines realia as the units of national language, indicating unique referents which are peculiar to this linguistic culture and absent in the comparable linguistic cultural community. The Bulgarian translators Vlahov and Florin, who were the first to carry out an in-depth study of realia, coined the modern sense of the word. According to classification of Vlahov and Florin, realia can be ethnic, domestic, cultural and historical. In this research we 
mostly deal with cultural and geographical realia, though historical and ethnic ones are mentioned in the work as well.

In this article we define «realia» as language units that nominate the phenomena of a «different» culture, bear a national, historical, local or everyday connotation and are characterized by a lack of equivalents in other languages and linguistic cultures.

The material for the research is the novel «Jazz» (1992) by Toni Morrison who is known as one of the most famous modern African-American writers. In this work, Morrison develops the concepts that shaped her previous five novels, creating a completely different kind of narrator and structuring the novel as a jazz music composition. This research focuses on a linguacultural component in the novel, it analyzes the features of various realia which are used to convey the national and cultural atmosphere in the novel. The study is conducted in the multicultural aspect.

The main theme of the novel was evoked by a photograph in James Van Der Zee's book 'The Harlem Book of the Dead' which shows a dead body of a young Afro-American woman. The story behind the photograph says that the girl was killed by her lover but when dying didn't reveal his name. The exposition of the novel is presented in the first few paragraphs: a disappointed middle-aged couple, Joe and Violet Trace, find themselves in emotional tragedy when Joe has an affair with an 18year-old neighbour, Dorcas, whom he loved «with one of those deep down, spooky loves that made him so sad and happy he shot her just to keep the feeling going» [11, p. 1]. Having found out that Dorcas was unfaithful to him, a 50-year-old Joe Trace kills the young girl. Dorcas, like the woman in Van Der Zee's photograph, refuses to tell anyone who shot her or to search for help as she gently dies. Violet Trace, the wife of Joe Trace, appears at Dorcas's funeral and, seeking revenge, attempts to cut the dead girl's face, after which she receives the nickname 'Violent'. The storyline turns to the questions of how and why the characters created these series of events. More than a few subplots widen, each entailing a return to Southern origins from the present events in the New York City, the author uses a string of toponyms to enhance the feeling of the Modern City as well as the hot African South.

Further, the story is enriched by multiple retrospective narratives and memories of the main characters (Violet Trace, Joe Trace, Alice Manfred, Dorcas and Felice), each of them telling their own story and demonstrating their own view on the same events. Such a narrative manner of Toni Morrison destroys the canon of traditional narrative, creating a jazz polyphony instead, which is characterized by the principles of decentration and de-hierarchization. Therefore, each character plays their solo part, and only the mutual combination of all solo voices in one 'jazz body' helps the reader to reconstruct a complete picture in the novel [17, p. 106]. Morrison skillfully plays with words describing the sadness of Joe Trace, one of the main characters in the novel:

«Blues man. Black and bluesman. Blacktherefore blue man.

Everybody knows your name.

Where-did-she-go-and-why man. So-lonesome-I-could-die man.

Everybody knows your name» [11, p. 226].

The lines resemble the lyrics of a song and have the rhythm and the beat of blues music, which vividly expresses the mood of the character.

In the novel the reference is often made to the past of the USA, thus a majority of realia reflect the life of African people through the history of American continent. In the novel «Jazz» the writer often mentions historical events and the past of African-American people as well as the protagonists. For example, she describes the riots taking place in the USA in summer 1917: "Crackers in the South mad cause 
Negroes were leaving; crackers in the North mad cause they were coming» [11, p. 154].

Anthroponyms, toponyms, national images, biblical motifs, symbols, allusions, authentic language of African slaves and musical motifs - are various multicultural features, which are skillfully used by T. Morrison in her novel.

In our work we pay special attention to onomastics, in particular anthroponyms and toponyms. For example, in order to better describe and disclose the nature of the main characters of the novel, the author carefully chooses their names in order to intensify their role and emphasize their behavior in the text. Anthroponyms in the novel reveal a detailed description of the characters and explain their actions. For example, Felice, whose name means happy, because she brings happiness to the dismal world of 'Jazz'; Golden Gray who exists thematically to point out the absurdity of racism as he is biracial and if he had darker skin, he would have been born a slave, True Belle who had all things organized, Rose Dear who is sweet and smiling all the time.

However, the brightest example is the name of the main character - Joe Trace, who chooses that name himself because of the fact that his foster mother told him that his parents vanished without a trace («disappeared without a trace»). Little Joe understood that as if his parents went missing without him - Joe. Also, the biological mother of Joe, is rumored to have lived in Vienna, Virginia, and Joe spent most of his childhood and early adult life looking for her. He found a path which she could follow and he tracked her in that way. In addition, he traces the ways in which Dorcas, his young lover, moves through the City when he wants to find her. Thus, the word 'trace' gives the character certain features, particularly the ability and desire to search and hunt. So, for Joe Trace the motif of tracking down and tracing is particularly important. Raised as a hunter, he remains a hunter even in the City, he can read the tracks and track his victims down.

Dorcas, the name of Joe Trace's lover, also has its special meaning. Dorcas (Greek: Dorkás; Aramaic: Tabītā) was a disciple who lived in Joppa and is mentioned in the New Testament. The name Dorcas is a Greek translation of the Aramaic name Tabitha, meaning 'gazelle'. In the novel Joe suspects his lover of being unfaithful and starts tracking her down, tracing her every step to make sure of his suspicions. In the Bible Dorcas is a woman who St. Peter brought back to life because of her charity work. In «Jazz» Dorcas dies in the first paragraph, but she lives through the novel in memories of Joe and Violet Trace, in her own reminiscences about the relations with Joe and her new love. She becomes the reason of the relationship between Alice Manfred (Dorcas's aunt) and Violet Trace, who wants to find out everything about the young girl. Thus, according to African beliefs while others remember and respect the name and memory of a person, she remains tied to the world of the living.

The image of the City, which the writer expresses through multiple narratives and a detailed description, reflects the atmosphere that prevailed in New York among African Americans at the beginning of the 20th century. "And when spring comes to the City people notice one another in the road; notice the strangers with whom they share aisles and tables and the space where intimate garments are laundered. Going in and out, in and out the same door, they handle the handle; on trolleys and park benches they settle thighs on a seat in which hundreds have done it too» [11, p. 25].

The author uses the names of shops (Duggie's drugstore), schools (PS-89, JHS 139), magazines (Modern Homemaker), streets (Lenox Avenue, East St. Louis), geographical names (Vesper County), names of companies (Southern Sky) in order to create a vivid American world which she portrays through the lenses of the AfroAmerican people who 
inhabit it: «... the stink of Mulberry Street and Little Africa, then the flesh-eating rats on West Fifty-third» [11, p. 32]. Here she compares some streets of the City with Africa, emphasizing the poor quality of life in both of these places. Some of the realia can be only understood in the context of American culture, thus they need a more thorough philological research: «So from Lenox to St. Nicholas and across 135th Street, Lexington, from Convent to Eighth I could hear the men playing out their maple-sugar hearts, tapping it from four-hundred-year-old trees and letting it run down the trunk, wasting it because they didn't have a bucket to hold it and didn't want one either» [11, p. 33]. Most of allusions go way back to the African origin of the protagonists and interwind with the realia of American society.

Symbols, for instance birds in a cage, which symbolize slavery, enrich T. Morrison's novel. The motif of freedom, which is realized by the act of freeing her pet-parrot by Violet Trace, is viewed from a different angle by the author: «That Violet should not have let the parrot go. He forgot how to fly and just trembled on the sill...» [11, p. 21]. Someone, who has been lacking freedom for so long, doesn't know what to do with it and can even suffer more from it that from the imprisonment in a cage. Morrison often focuses on the harrowing conditions of live of the African people in the USA at the beginning of the $20^{\text {th }}$ century. For example, she describes the total helplessness of black people who often have to work for free or for very low wages or raise the children of white men instead of their own ones (as it did True Belle, Violet's grandmother).

In the novel readers can also see a large number of allusions and African American Vernacular English (AAVE) which is spoken by protagonists of the novel, like Joe and Violet Trace: "You look froze.» / "Near bout," said Violet. / "March can put you in the sickbed.» / "Be a pleasure,» Violet answered. "All my troubles be over if I could get my body sick stead of my head» [11, p. 276]. The use of African dialect helps us experience the African-American identity of characters in full. Also, in this way the writer emphasizes the relationship between language, life and culture.

In conclusion, in the novel «Jazz» Toni Morrison uses various features to express the multicultural identity of its characters through various cultural realia - the use of African dialect, toponyms and anthroponyms, authentic African imagery and musical rhythm of African nation.

\section{References}

1. Ahmanova O.S. Slovar lingvisticheskih terminov. 2-e izd., ster. Moskva: URSS: Editorial URSS, 2004. $571 \mathrm{~s}$.

2. Denisova T.N. T. Morrison. Istoriya zarubezhnoy literaturyi XX veka. / Pod red. L. G. Mihaylovoy i Ya. N. Zasurskogo. Moskva: TK Velbi, 2003. S. 363.

3. Musina N.M. Realia as a cultural phenomenon. Molodoy uchenyiy. 2017. \#22. S. 481-484. URL: https://moluch.ru/ archive/156/43949/ (2020, February 16).

4. Popova M.K. Problema natsionalnoy identichnosti i literatura. Vestnik $V G U$. Seriya 1: Gumanitarnyie nauki. 2001. \# 2. S. 45-48.

5. Tlostanova M.B. Problema multikulturalizma i literatura USA kontsa XX veka. Moskva, IMLI RAN, Nasledie, 2000. S. 328 .

6. Tolkachev S.P. Multikulturaliz $\mathrm{m} \quad \mathrm{V}$ postkolonialnom prostranstve i krosskulturnaya angliyskaya literatura. Informatsionno-gumanitarnyiy portal «Znanie. Ponimanie. Umenie». 2013. \# 1 (January-February). URL: http://www. zpu-journal.ru/e-zpu/2013/1/Tolkachev Multiculturalism-Cross-culturalLiterature (2020, February 16).

7. E-journal USA. Multicultural Literature in the United States Today. US Department of State. February 2009. Vol. 14. N. 2. P. 4. URL: https://kr.usembassy.gov/wpcontent/ uploads/sites/75/2017/04/Multicultural.pdf (2020, February 11). 
8. Gates, Henry Louis, Jr. The Signifying Monkey: A theory of African-American Literary Criticism. Text. New York: Oxford University Press, 1989.

9. Gates, Henry Louis Jr. The blackness of blackness: a critique of the sign and the Signifying Monkey. Black Literature and Literary Theory. Ed by: Henry L. gates, Jr. N. Y.: Methuen Inc., 1984. P. 290.

10. Graaf, P.A.J. African American identity and translation challenges in Toni Morrison's «Jazz»: Faculty of Humanities Theses: MAThesis Translation Studies. 2012. 90 p.

11. Morrison Toni. Jazz. E-book. URL: www. go2reads.com/jazzonline-toni-morrison (2020, January 15).

12. Morrison T. Unspeakable Things Unspoken: The Afro-American Presence in American Literature. Within the Circle. An Anthology of African American Literary Criticism from the Harlem Renaissance to the Present I Ed. Angelyn Mitchell. Duke University Press, 1994. P. 368-400.

13. Sanders, Linda A. Chapter 19: Multicultural Literature in Performance: Evoking Shades of

Надійшла до редакиії 13.11.2019
Deeper Meaning. Curriculum and Teaching Dialogue. January-July 2009. p. 194.

14. Song, Sarah. Multiculturalism. The Stanford Encyclopedia of Philosophy (Spring 2017 Edition), Edward N. Zalta (ed.). URL: https:// plato.stanford.edu/archives/spr2017/entries/ multiculturalism/ (2020, February 11).

15. Taylor, Charles. Multiculturalism: Examining the Politics of Recognition. Princeton: Princeton University Press, 1994. P. 37-38. 51, 44, 51, 38.

16. Tony Morrison's. Fiction: Contemporary Criticism / Ed. by: David L. Middleton. Routledge: New York and London, 2015. $325 \mathrm{p}$.

17. Williams Lewis, Barbara. The Function of Jazz in Toni Morrison's Jazz. Tony Morrison's fiction: contemporary criticism / Ed. by: David L. Middleton. Routledge, NY, 2015. P. xvi.

18. Yokota, J. (1993). Issues in selecting multicultural literature. Language Arts, 70, 156-157.

19. Young, I.M. (1990). Justice and the Politics of Difference. Princeton, NJ: Princeton University Press. 